\title{
Az ionizáló sugárzás emberi szervezetre gyakorolt hatásának korszerü kimutatási lehetőségei
}

\section{Deli Gábor}

Kulcsszavak: biodozimetria, mikronukleusz, kromoszóma aberrációk, $\gamma$-H2AX, comet esszé, mitokondriális DNS, mRNS és fehérje markerek

Az ionizáló sugárzás gyakrabban éri szervezetünket, mint gondolnánk. Tartósan ki vagyunk téve a földkéregből és a kozmikus térből érkező háttérsugárzásnak. Katasztrófa, sugaras esemény vagy terrortámadás esetén az emberek nagyobb dózisú ionizáló sugárzást kaphatnak. Ezek az expozíciók - dózisfüggő heveny megbetegítő hatásokon túl - hosszú távú egészségügyi problémákat okozhatnak, rosszindulatú daganatok alakulhatnak ki a besugárzást követö években. Azokban az esetekben, amikor az érintett személyek nem viselnek személyi dozimétert, az elszenvedett dózis különböző biodozimetriás eszközökkel becsülhető meg. Ezeknek a módszereknek a közös jellemzője, hogy az egyén sejtjeiben az ionizáló sugárzásnak való kitettség során bekövetkező dózisfüggő változásokat detektálják, ezzel lehetővé téve a becsült dózisra alapozott terápia megtervezését. A besugárzás hatására kromoszóma-rendellenességek figyelhetők meg, ezek közül az egyik, a dicentrikus forma, specifikus az ionizáló sugárzásra. E klasszikus referencia módszer fő hátrányai az időigényes sejttenyésztés és a szubjektív mikroszkópos értékelés. Nagyobb számú ember érintettsége esetén, az elöszüréshez, és a továbbvizsgálandó embercsoport létszámának csökkentéséhez néhány gyorsabb vizsgálati eljárásra is szükség van. Számos biodozimetriás eljárás már rendelkezésre áll vagy fejlesztés alatt van. A mikronukleusz vizsgálat egy egyszerübb citogenetikai módszer, bár szintén időigényes, de az értékelés gyorsabb. A fehérjemarkerek szintén hasznos eszközök lehetnek, például a $\gamma$-H2AX hisztonfehérje, amely jelzi a DNS kettős szálú törését. Az comet assay egy sejt szintü elektroforézis, a törött DNS „üstököst” formáz a gélben, és minél több helyen törött a DNS, annál hosszabb az üstökös csóvája. A mitokondriális DNS érzékenyebb a sugárzásra, mint a sejtmagi DNS. A javítási folyamat hibájának eredményeként kialakuló deléciói PCR módszerrel kimutathatók. Sugárhatásra expresszált fehérjék és mRNS-eik szintén kimutathatók. Ez az összefoglaló rövid áttekintést nyújt a biodozimetriás módszerekről. 
A terrorizmus és különböző balesetek általi fenyegetettség elörevetíti annak a lehetőségét, hogy nagy tömegek legyenek kitéve ionizáló sugárzásnak. Az erre való felkészültség magában foglalja a különböző biodozimetriai módszerek alkalmazását, annak érdekében, hogy az elszenvedett dózis hatására létrejövő (egészség) károsodást felbecsülhessük, a várható következmény súlyosbodását csökkenthessük, a megfelelö terápiát kiválaszthassuk. A biodozimetria fontos szerepet játszhat radiológiai eseményeknél, mivel a dózis becslése nagyban megkönnyíti a sérültek orvosi szempontból történő besorolását. A biodozimetria segíthet: megbecsülni azt, hogy hány ember szenvedett el olyan dózist, ami nem igényel akut ellátást; segít osztályozni azokat a sérülteket, akiket tovább kell irányítani az ellátás kategóriáját illetően; elkezdeni a tényleges kezelést, valamint segíti az ellátó személyzetet és a sérülteket az ionizáló sugárzásnak való kitettség hosszútávú következményeinek kezelésében, mint például a kezelések megtervezése, vagy az esetleges kompenzációk [1].

Definíció szerint minden biodozimetiai módszer olyan változásokat detektál, amelyek az egyén sejtjeiben, vagy szöveteiben alakulnak ki ionizáló sugárzásnak való kitettség hatására, és amely olyan paramétereket számszerüsít, melyek megbízhatóan a kapott dózisnak tulajdoníthatóak [2].

$\mathrm{Az}$ elérhető biodozimetriai módszerek többsége „biológiai alapú”, azaz a sugársérülésre kialakuló közvetlen, vagy közvetett biológiai választ (szomszédsági hatás) detektálják [3]. A biológiai alapú módszerek egyik alaptípusa a fehérvérsejtekben bekövetkező változásokat detektálja (citogenetikai módszerek: DIC, MN, PCC, FISH). A másik alaptípus pe- dig a DNS-károsodás és repair, génaktiváció, metabolom és proteom biomarkereit vizsgálja. Általában ezen válaszok normál funkciója a patofiziológiai folyamatokra és fizikai sérülésekre történő válaszadás; ezért ezek nem specifikusak az ionizáló sugárzásra [2].

$\mathrm{Az}$ eredményeket egyéb faktorok is befolyásolják, mint a kor, betegségek, stressz, életmód és a nem [4]. Sugárterhelés gyanúja esetén a legáltalánosabban elvégzett vizsgálat a vérkép vizsgálata, mivel a sugárzás hatására a vér sejtes elemeinek a száma lecsökken [5]. Ez azonban dózisbecslésre csak korlátozott mértékben alkalmazható, hiszen a vérképet számos egyéb tényező is nagymértékben befolyásolhatja (gyógyszerek, megbetegedések).

$\mathrm{Az}$ ideális biodozimetriai eljárás sugárzás-specifikus, alacsony hátterü és szórású, dózis-hatásra kalibrálható, hosszantartó hatást mér, könnyü a mintavételezés és gyorsan jutunk eredményhez és aránylag könnyen kiszürhetőek a hamis pozitívok és negatívok [6]. Míg egyik módszer sem teljesíti az ideális doziméter kritériumát, egy egységes, az eseményekre szabott megközelítés felelhet meg a legtöbb elvárásnak, ahol több módszert alkalmaznak egyidejüleg [7].

Tekintve, hogy ezeknek a módszereknek sok esetben igen eltérö lehet az időigénye, a kimutathatóság időablaka és az áteresztőképessége, fontos, hogy egymás mellé tudjuk őket álltani, hogy katasztrófahelyzetben ki tudjuk választani a legmegfelelőbb módszert, vagy módszereket. Jelen közleményben célul tüztem ki a jelenleg legelterjedtebb biodozimetriai módszerek leírását, illetve az ilyen célra potenciálisan alkalmazható korszerü eljárások ismertetését. 


\section{Citogenetikai módszerek}

$\mathrm{Az}$ ionizáló sugárzás által a perifériás limfocitákban okozott citogenetikai sérülések vizsgálata biodozimetriai célból általánosan elterjedt. Az egyes módszerek alkalmazhatósága a kromoszómasérülés stabilitásától, típusától, a sejtek osztódásástól és szelekciójától függ. A dicentrikus kromoszómák, PCCfragmentek és a mikronukleuszok frekvenciája elöfordulási gyorsasága csökken a limfociták cserélődésével (ún. instabil kromoszóma hibák), ilyen módon ezek a módszerek a néhány hónappal korábbi besugárzás nyomait még kimutatják, régebbi besugárzások esetén a FISHkromoszómarészlet transzlokáció vizsgáló módszer a legjobb választás, mivel az stabil transzlokációkat mutat ki.

\subsection{Dicentrikus kromoszóma analízis}

A dicentrikus kromoszómák csaknem kizárólag sugárzás hatására keletkeznek [8], két közeli dupla szálú DNS-törés hibás kijavításával. Ezért a dicentrikus kromoszóma vizsgálat az a módszer, amit gold standard-nek tartanak [9]. A dózistartomány és az időablak megfelel a biodozimetriai vizsgálatokhoz, viszont a vérminta további tenyésztését és az osztódás indukcióját is igényli a módszer, mivel a kromoszómák csak osztódó sejtben láthatók. A feldolgozás mikroszkóppal történik.

A centromer régió egy befüződés a kromoszómán, ez a húzófonalak tapadási helye. Az itt található kinetokór fehérjék biztosítják a kapcsolatot a DNS és a húzófonalak tubulinja közt a sejtosztódás során. Az ionizáló sugárzás hatására törések keletkeznek a kromoszómákon, az eltört végek pedig nem megfelelően „forrnak össze”. Két centromer tartalmú rész fúziójából dicentrikus kromoszóma jön létre, azok a darabok, amik nem tartalmaznak centromert fragmentként maradnak vissza. Ritkán tricentrikus és gyürű alakú kromoszóma is létrejöhet. A vizsgálat során olyan kromoszómák számolása történik, melyeknek két centromer régiója van.

A dicentrikus kromoszómák frekvenciája keringő limfocitákban tisztán lineáris-kvadratikus dózis-hatás összefüggést mutat megközelítőleg 5Gy-ig, akut sugárzás esetén. Az egészséges populációban meglehetösen alacsony a spontán dicentrikus háttér ( $\sim 1$ dicentrikus/1000 sejt). Ennek az alacsony háttérnek köszönhetően a módszer érzékenysége jó, képes kimutatni $\sim 0,1$ Gy egésztest dózist 500-1000 metafázis vizsgálatával [10, 11]. A sok munkaórát igénylő mikroszkópos értékelésen kívül a módszer hátránya, hogy a dicentrikus kromoszómák a limfociták cserélődésével eltünnek, így a korábban elszenvedett besugárzás esetén megbízható dózisbecslést csak meghatározott időközönként elvégzett vizsgálatok eredményeinek visszamenőleges extrapolációjával nyerhetnek, vagyis ilyenkor csak mérsékelten használható az eljárás (1. ábra).

Előnyösek lehetnek azok a módszerek, melyek genotipizálásra is használhatók, ez ugyanis napi rutinfeladat számos laboratóriumban, és ezek az eljárások mintafeldolgozásban és értékelésben sokban hasonlítanak a biodozimetria citogenetikai eljárásaihoz. A genotipizálásra alkalmazott automata mikroszkóprendszerek sugárhatás értékelésére is alkalmasak. Ilyenek a LUCIA, a Metafer mikroszkóprendszerek, de ezek csak félautomatikus megoldások, a kromoszóma vizsgálati eredményt mindenképpen manuálisan is ellenőrizni kell. 

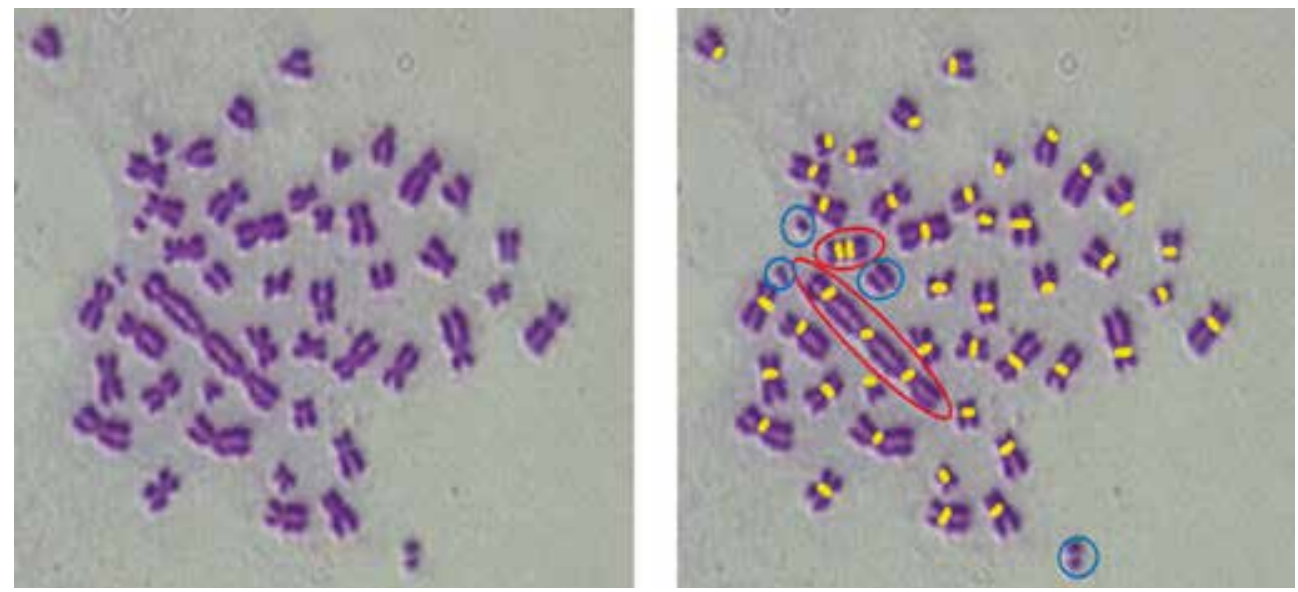

1. ábra. Osztódásban, (metafázis) lévö, besugárzott (4 Gy, röntgen) limfocita kromoszómái. Dicentrikus és tricentrikus kromoszómával, acentrikus fragmentekkel

\subsection{Mikronukleusz teszt}

$\mathrm{Az}$ in vitro cytokinezis-blokkolt mikronukleusz (CBMN) módszer egy másik biodozimetriai eljárás. A módszer technikailag hasonlít a dicentrikus kromoszóma analízisre, de egyszerübb annál. A vizsgálat osztódásra késztetett, de citokinézisben blokkolt, ún. binukleáris limfocitákon történik. (Ez garantálja azt, hogy csak az első generációs utódsejtek kerüljenek értékelésre.)

Mikronukleuszok (MN) olyan acentrikus fragmentekből, vagy sérült, egész kromoszómákból keletkeznek, amelyek nem tudnak a leánysejtek magjába vándorolni a sejtosztódás során [12]. Ezek a binukleáris leánysejtek citoplazmájában jól elkülönülő kis szférikus testekként jelennek meg, melyeknek ugyanaz a morfológiája, valamint a festődési tulajdonságai, mint a sejtmagoknak [7] (2. ábra).

A mikronukleuszok megjelenése nem sugárzásspecifikus: a sugárzáson kívül számos klasztogén és aneugén anyag hatására képződhetnek. A mikronukleusz módszert a toxikológiában is alkalmaz- zák [7]. Akárcsak a dicentrikus kromoszómák, a mikronukleuszok sem stabil citogenetikus aberrációk, melyek a periférias vér természetes megújulása során idővel eltűnnek a besugárzás után, így a módszer használhatósága limitált a több évvel ezelőtti besugárzások esetén.

A módszer alsó kimutatási határa 0,2-0,3 Gy [10]. A korral nagymértékben és nagy variabilitással nő a spontán mikronukleusz képződés, különösen a nők esetében [13].

A mikronukleusz teszt jóval könnyebben számolható, rövidebb mikroszkópos feldolgozást igényel, mint a dicentrikus kromoszóma vizsgálat. A módszer időablaka és a dózistartománya megfelel dozimetriai célokra.

Vannak törekvések a módszer automatizálására, például LUCIA [14], RABIT [15], Metafer mikroszkóprendszerek [16]. A problémát a citoplazma detektálása jelenti, a régebbi rendszerek nagy sejthígítással dolgoznak, és csak a magok távolsága alapján döntenek a binukleáris sejtek mikronukleuszairól. 


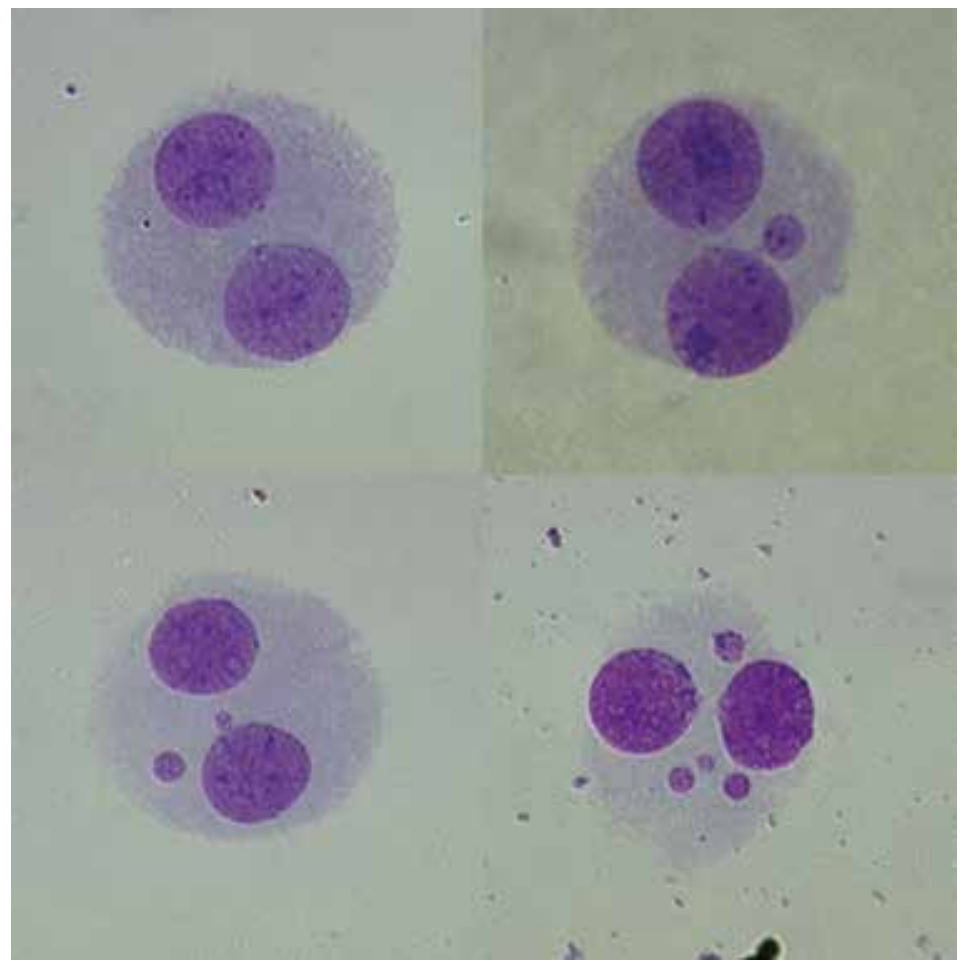

1. ábra. Osztódásban (telofázis) lévö, besugárzott (4Gy, röntgen) limfociták 0-1-2-4 mikronukleusszal

\subsection{Premature Chromosome Condensation (PCC)}

(Korai Kromoszóma Kondenzáció)

A sejtfúziós PCC egy lehetséges biodozimetriai módszer [17] olyan sugársérülések esetén, ahol a gyors és pontos dózisbecslés az elsődleges prioritás [18]. A PCC során nem stimulált limfocitákat fuzionáltatnak éppen osztódásban lévő kínai hörcsög ovárium sejtekkel $(\mathrm{CHO})$ polietilén-glikol (PEG) jelenlétében. Az ilyen sejtekkel keveredés hatására a nyugalmi, nem osztódó linfocitákban azonnal beindul a magállomány rögösödése (kondenzációja), vagyis a kromoszómákba tömörülés mesterségesen indukált, felgyorsított folyamata. A módszer segítségével a Giemsa-val megfestett PCC-fragmentek és gyürük száma gyors dózisbecslést tesz lehetővé $[19,20]$. Különösen igaz ez, ha a PCC-t kombinálják C-sávozással [21], fluorescens in situ hibridizációval (FISH), specifikus DNS-könyvtárak használatával vagy telomer-centromer (TC) festéssel, nukleinsav (PNA) probe-ok használatával. Ez utóbbi esetben lehetőség van a PCC fragmentek és transzlokációk mellett a dicentrikus kromoszómák és centrikus gyürűk detektálására is, így gyors és pontos dózisbecslést adni [22, 23, 24].

A módszer használható alacsony dózistartománytól egészen az életveszélyes akut dózisokig, kis és nagy LET-értékü sugárzások mellett. Lehetőség van különbséget tenni a teljes-, és résztest besugárzás között, mivel a sejteket nem tenyésztik és/vagy stimulálják, a normál sejtek eloszlása jól tükrözi a besugárzást nem kapott limfociták arányát a 
keringő vérben. A PCC-vizsgálat során a fúzió során kialakult, a 46 normál kromoszómán felüli PCC-fragmentek számát vizsgálják. A spontán kialakuló PCC fragmentek száma a dicentrikus kromoszómákhoz hasonló nagyságrendü, $1-3 / 1000$ sejt.

Nagyon különböző eredményeket kaphatunk aszerint, hogy hány órával a feltételezett sugárterhelés után történt a vérvétel. Amennyiben a mintavétel késve történik, a repair mechanizmusokkal is számolnunk kell az értékelés során. Vizsgálatok kimutatták, hogy 4 órával a besugárzás után a PCC-fragmentek száma duplája volt az 1, illetve 7 nappal későbbi értékeknek, míg az 1 és 7 napos értékek között nem volt szignifikáns eltérés [25].

\subsection{Fluorescent in Situ Hybridization (FISH)}

A FISH-módszert több éve használják a múltbéli sugárkárosodások becslésére. A legelterjedtebb verziója az egyszínủ FISH (sFISH), amely lehetővé teszi a kromoszómák közötti változások detektálását, úgymint dicentrikus kromoszómák és transzlokációk. Annak érdekében, hogy a különböző, jelölt kromoszómák közötti transzlokációkat is értékelni lehessen, kifejlesztették a többszínü FISH-t (mFISH), a teljes genom analízishez, pedig a multiplex FISH-t (M-FISH). Továbbá használnak még páncentromerikus és telomerikus probe-okat, különböző kromoszóma festék probe-okkal kombinálva, így pontosan elkülöníthetők a transzlokációk és a dicentrikus kromoszómák, illetve az egy- és kétirányú transzlokációk. Általában a transzlokációkat vizsgálják az időben elhúzódó besugárzásoknál (pl.: foglalkozási sugárártalom) és a múltban történt besugárzások becslésénél. A transzlokációk frekvenciája több évig állandó a kerin- gö limfocitákban [26, 27, 28, 29], azonban a háttérfrekvencia jelentősen nő a korral $[30,31]$ és jelentősen eltérhet hasonló korú és hasonló dózist elszenvedő személyek között. Az eredmények arra mutatnak, hogy sem a nem, sem a rassz nem befolyásolja a háttérfrekvenciát, azonban a dohányzás feltehetően igen [31].

A detektálás alsó határa 0,5 Gy környékére tehető kummulatív dózisban [29], azonban fiatal, nem dohányzó személyek esetén 0,2 Gy is kimutatható. Résztest besugárzás esetén a sejtek, amelyek a transzlokációkat hordozzák, gyakran instabilak, így a frekvencia az idővel csökken [29]. Mivel a vizsgálathoz hosszas hibridizációs folyamatra és osztódó limfocitákra van szükség, a minta kézhezvételétől számított $\sim 5$ nap alatt adhat eredményt.

A FISH-technikák alkalmazhatók olyan esetekben is, ahol az érintettek nagy LET-értékü sugárzásnak voltak kitéve. Plutóniummal dolgozó munkások esetén megnövekedett transzlokációs frekvenciát mutattak ki évekkel a besugárzás után [7]. Egyéb aberrációk is alkalmas biomarkereknek tünnek magas LET-értékű sugárzás esetén, mint az inzerciók, intra-kromoszómális és komplex aberrációk.

Két EU-megállapodás, amely az sFISH standardizálását célozta meg, azzal zárult, hogy csak a „teljes” sejtek használhatóak a vizsgálatokhoz, azaz ahol minden megjelölt elem jelen van, illetve 46 kromoszóma van jelen. Szintén csak ezek a sejtek használhatóak a becsléshez is. Populáció alapú vizsgálatokhoz $\sim 300$ genom ekvivalens sejt szükséges személyenként. A pontos dózisbecsléshez személyenként $\sim 1000$ genom ekvivalens sejtre van szükség [7]. Vannak próbálkozások automatizálásra pl. LUCIA automatizált mikroszkópos kontrollrendszer [14]. A módszert genetikai vizsgálatokra rendszeresen hasz- 
nálják, de jó alkalmazhatósága ellenére kevéssé elterjedt biodozimetriai célokra, mivel kivitelezése sok gyakorlatot igényel és a többi eljáráshoz képest drágább.

\section{Fehérje, DNS és RNS markerek (molekuláris biológiai módszerek)}

Ionizáló sugárzás hatására nemcsak a nukleinsavak (DNS, RNS) károsodnak, de a sugárzásra adott válaszreakció során egyes gének aktiválódnak, míg mások deaktiválódhatnak, változik az egyes gének expressziós szintje [7]. Mind a DNS károsodások, mind a génexpresszió változásának kimutatására lehetőség van.

A sugárzásra adott válasz folyamán a fehérjék mennyisége, lokalizációja is megváltozik, illetve számos enzimatikus módosítás történik sejt-, szövet és szervezet szinten. Ezek a változások proteomikai módszerekkel kimutathatóak vizeletből, vagy vérből. Számos technika áll rendelkezésre az egyes fehérjék besugárzás utáni vizsgálatára. Ezen módszerek egyik legnagyobb elönye, hogy mivel szinte minden esetben modern, automatizált eljárásokról van szó, a minta átvételétől az eredményig eltelt idő általában néhány óra [7].

\section{1. $\gamma-\mathrm{H} 2 \mathrm{AX}$}

Kettős szálú DNS törés esetén a H2AX hisztonfehérje a 139-edik helyen foszforilálódik, ez a repair mechanizmus első lépése. A foszforilált hisztonfehérje immuncitokémiai kimutatása során kialakuló fluoreszkáló pontok (fókuszok) jelenléte érzékeny indikátora a magi DNS töréseinek. A besugárzás után csak rövid ideig vizsgálható (24-48 óra), mert a DNS javító enzimek rövid idő alatt sok törést kijavítanak. A mikroszkópos feldolgozás során a fókuszok összeszámolása szükséges [7, 32, 33].
A legkárosabb hatás, amit az ionizáló sugárzás okozhat a sejtben, a kettős szálú DNS lánctörés (DSB). A sejtek gyorsan reagálnak a keletkező törésekre, annak érdekében, hogy behatárolják és kijavítsák őket olyan gyorsan és olyan hatékonyan, amennyire csak lehetséges, hiszen a hibásan kijavított törések daganatos elváltozásokhoz, illetve sejthalálhoz vezethetnek. Osztódó sejtekben a sejtciklus leáll a javítás idejére. Mindkét folyamat - a hibajavítás és a sejtciklus leállítása -, amelyek számos fehérje aktiválódásával és gének átíródásával járnak, kapcsolódik a sejtciklushoz, illetve a növekedés szabályozásához [34].

A duplaszálú DNS lánctörés (DSB) - amely az ionizáló sugárzás azonnali hatása -, kimutatható $\gamma-\mathrm{H} 2 \mathrm{AX}$ antitesttel, amely a H2A hiszton H2AX variánsának foszforilált formája, amely gyorsan kialakul a DNS eltört szakaszain [35, $36,37]$.

Mivel a $\gamma$-H2AX fókuszok kialakulása egy sejtválasz a duplaszálú DNS törésekre, a fókuszok száma csökken a lánctörések kijavításával. A DNS kétszálú törései kétfázisú kinetikával javítódnak ki: a gyors fázis pár óráig tart, melyet egy lassú fázis követ [38].

Mivel a $\gamma$-H2AX fókuszok száma mind az elszenvedett dózistól, mind az eltelt időtől függ, csakúgy, mint az adott sejttípustól, ezért ahhoz, hogy pontos becslést tudjunk adni a dózisról, ismernünk kell a besugárzástól eltelt időt [39].

Vannak törekvések a módszer automatizálására, például a RABIT-munkaállomás [40].

\subsection{Comet assay}

Az 1 Gy dózisú röntgensugárzás kb. 1000 db egy-láncú és $40 \mathrm{db}$ kétláncú DNS-törést okozhat a sejtekben [41]. A comet 
esszével a DNS egyláncú és kettős láncú törései is kimutathatók [42].

A módszer alapja sejtszintű agaróz gélelektroforézis. A sejt elmozdulását megakadályozzuk azzal, hogy alacsony olvadáspontú $\left(37^{\circ} \mathrm{C}\right)$ agaróz szuszpenzióba ágyazzuk, majd a sejtet lizáljuk, és elektrofozézist végzünk lúgos $(\mathrm{pH}>13)$ vagy semleges közegben, attól függően, hogy minden (egyláncú és kettős láncú), vagy csak a kettős láncú DNS töréseket szeretnénk kimutatni. Magas $\mathrm{pH}-\mathrm{n}$ ugyanis a DNS denaturálódik, egyláncú lesz.

A lizált sejt elektroforézise során a DNS elmozdul a gélben, annál meszszebbre, minél jobban károsodott, minél kisebb darabokra tört a molekula a sugárzás hatására. DNS specifikus fluorescens festékkel festve a mikroszkópos kép alapján értékelhetö az elmozdulás mértéke. A „comet” nevet a teszt a DNS-folt jellegzetes alakja miatt kapta, a gélben történő migráció során olyan forma alakul ki, amely üstökösre (comet) emlékeztet. A comet assay, amelyet gyakran hívnak „egy sejt elektroforézisnek" is egy érzékeny, gyors és kényelmes módszer a DNS-károsodások és repair mechanizmus sejtszintü vizsgálatára [43], így alkalmas lehet sugárérzékenység becslésére is [43, 41].

A módszer előnye, hogy nem kellenek hozzá osztódó sejtek. Biodozimetriai célokra csak rövid mintavételezési időkorlátok között alkalmas, mivel az élő sejtek gyorsan kijavítják a DNS-töréseket. Az időkorlát rövid: 0,5-4 óra [44] a detektálhatósági határ 0.05 Gy [45]. A módszer alkalmas lehet az egyéni sugárérzékenység megállapítására, ami kombinációban más biodozimetriai módszerekkel pontosabbá teszi azok eredményének értékelést, bár az összefüggés ellentmondásos [41].

\section{3. mRNS markerek}

A nagy tömegeket érintő nukleáris és/vagy radiológiai balesetek miatti fenyegetettség - ahol több ezer ember lehet érintett -, szükség van egy gyors biodozimetriai módszerre a triage céljából. Bíztató eredményeket értek el mind genomikai, mind proteomikai megközelítéssel [46].

Ismert tény, hogy az emberi sejtekben különféle környezeti stressz hatására, mint például az ionizáló sugárzás, különböző jelátviteli utak aktiválódnak és a génexpressziós mintázat gyors, összetett változása is bekövetkezik. Mind az alapvető génexpressziós mintázat, mind a sugárzásra adott válasz összefüggést mutat az egyes sejtvonalak sugárérzékenységével. Az egyes gének expressziója lehet dózis- és stresszfüggő, és a megváltozott génexpresszió fennmaradhat akár napokig is a besugárzást követően, így lehetőséget biztosítva dozimetriai becslésekre [47].

Azok között a fehérjék között, amelyek részt vesznek a DNS-károsodás észlelésében, illetve a sejtciklus szabályozásában a H2AX, az ATM, a CDKN1A és a TP53 potenciális biodoziméterek lehetnek, de számos egyéb fehérje is alkalmas marker lehet ilyen célokra (például DXR, BAX, DDB2, ACTN1) [48].

A génexpressziós módszer kulcslépései a következők: RNS-extrakció, jelölés és hibridizáció. Ezen lépések mindegyikére rendelkezésre állnak jól definiált protokollok. Míg a génexpressziós módszerek kiváló eszközök a sugárválaszban résztvevő gének azonosítására kis mintaszám esetén, addig a kvantitatív reverz transzkripciós real-time polimeráz láncreakciós módszerekkel (qRT-PCR) kisszámú sugárválasz gén expressziós szintje határozható meg pár órán belül, akár több száz minta esetén is. 
Jelenleg igen kevés tanulmány foglalkozik a sugárzásra való specificitással és számos exogén faktor zavaró hatását is vizsgálni kell még. Az egyes sugárzástípusokra adott válaszok közötti különbségek szintén ismeretlenek. Ahhoz, hogy a módszer megbízható doziméter lehessen a jövőben, a bizonytalanságát és alkalmasságát is meg kell vizsgálni olyan összetett események esetében, mint például egy résztest besugárzás [7].

\subsection{A mitokondriális DNS}

Az emberi mitokondriális DNS (mtDNS) egy 16,6 kb hosszú gyürüs, duplaszálú DNS molekula, amely 13 esszenciális polipeptidet és számos RNS- $t$ ( 2 rRNS és 22 tRNS) kódol [49]. A kódoló szakaszok között egy 1,1 kb. hosszú nem kódoló szakasz helyezkedik el, melyet D-huroknak neveznek és a mitokondriális replikáció és transzláció inicializálásáért felel [50]. Egy sejt citoplazmájában több mitokondrium is található és mitokondriumonként 2-10 mtDNS molekula lehet jelen, így sokkal nagyobb kópiaszámban fordul elö sejtenként, mint a magi DNS. A mitokondriális DNS-hez nem kapcsolódnak védő funkciót betöltő hisztonfehérjék, mint a magi DNS esetében, ami fokozott kockázati tényező, tekintve az oxidatív foszforilációból származó reaktív oxigéngyökök okozta folyamatos oxidatív stresszt. Mindez a mitokondriális DNS viszonylagosan gyenge repair képességeivel együtt azt eredményezi, hogy az mtDNS sokkal sérülékenyebb az oxidatív hatásokkal szemben, mint a magi DNS.

$\mathrm{Az}$ ionizáló sugárzás indirekt hatásaként reaktív oxigéngyökök szabadulnak fel, amelyek további károsodást okoznak a sejtekben. Tekintve, hogy a mtDNS ezekre a hatásokra érzékenyebb (mivel a mitokondriális membrán tartalmazza a légzési transzport és a terminális oxidáció enzimeit) és a kópiaszáma is magas, molekuláris biológiai módszerekkel a DNS károsodásának mennyisége potenciálisan érzékeny marker lehet az elszenvedett dózis kimutatására.

$\mathrm{Az}$ oxidatív sérülések következményeként a DNS molekulákon törések alakulhatnak ki, melyek érinthetik csak az egyik láncot, vagy súlyosabb esetben kettősszálú törést is okozhatnak. A mtDNS hibajavítási sajátosságaiból adódóan elöfordulhat, hogy ezek a törések nem a megfelelő módon kerülnek kijavításra. A mtDNS cirkuláris molekula, bizonyos szakaszok a hibajavítás során kieshetnek a genomból, így deléciók alakulnak ki. Ezek a deléciók többnyire konkrétan meghatározható pontokon alakulnak ki, számos ilyen deléciót leírtak már [51]. Ezek a deléciók PCR technikával kimutathatók, így az oxidatív károsodásra, közvetetten pedig az elszenvedett sugárdózisra hordozhatnak információt.

\section{Biofizikai technikák}

\subsection{Optikailag stimulált lumineszcencia eljárás (OSL)}

A dózisbecslés biofizikai technikái meglehetősen fejlettek. Az optikailag stimulált lumineszcencia eljárás (OSL) lehetővé teszi a dózisbecslést azáltal, hogy a besugárzott tárgyak által kibocsátott fényt méri. Olyan testrészek, mint a fogak, vagy személyes tárgyak, mint a kerámia protézisek, mobiltelefonok és egyéb elektronikai eszközök, alkalmasak ezekre a vizsgálatokra. Az OSL előnye, hogy erősen specifikus a sugárzásra és érzékeny is (a kimutathatóság alsó határa a mGy-es tartományban van, míg a felső határa néhány Gy), azonban nagy hátránya, hogy a mért jel nem stabil az időben [52]. 


\subsection{Elektron spin rezonancia (EPR)}

Az ESR (elektron spin rezonancia), vagy EPR (elektron paramágneses rezonancia) olyan technika, amely képes mérni a sugárzás által keltett gyököket olyan biológiai anyagokban, mint fogzománc, csont, köröm, de ember által alkotott tárgyakban is. Az ESR érzékenysége igen jó, meglehetôsen széles dózistartományban (1-1000 Gy) és a mért jel is évekig stabil marad. Hátránya, hogy viszonylag magas az alsó kimutatási határa (50 mGy) és nem érzékeny alacsony dózisok esetén [52].

\section{Összegzés}

Nincsen a sugárzás észlelésére specializálódott érzékszervünk, utólag is csak a szervezet reakcióját észleljük. Minél nagyobb dózisú az elszenvedett sugárzás annál gyorsabban, és annál súlyosabb tüneteket okoz. Kis dózisú - egy Gy alatti sugárzás nem okoz rögtön tüneteket, de későbbi megbetegedések kiváltó oka lehet.

Az sugárzás hatására károsodott sejtek funkciókiesését a szervezet esetleg még kompenzálni tudja, azonban, ha a sérült sejt osztódni kezd, daganat is létrejöhet. Ha az ivarsejtek genomja sérül, akkor a következő generációba már veleszületett rendellenességként kerülhet át a sugársérülés. A veleszületett rendellenességek, és a sugárhatásra létrejött elváltozások között az a fö különbség, hogy míg az előbbi esetben minden sejtet érint az elváltozás, sugárhatásra csak néhány sejt károsodik. Így a sugárterhelés megállapítását célzó biodozimetriai adatgyüjtést még egy ember kapcsán is statisztikai feldolgozás követi. A biodozimetriai eljárások egyénenként nagyságrendekkel több sejt vizsgálatát igánylik, mint például a humángenetikai vizsgálatok, rendkívüli helyzetben gyorsan kell minél több embert vizsgálni, ezért a biodozimetriai szűrés, az egymásra épülő vizsgálatok megtervezése folyamán különösen nagy gondot kell fordítani a költséghatékonyságra és az időkihasználásra.

A biodozimetriai módszerek a közös jellemzője, hogy az egyén sejtjeiben az ionizáló sugárzásnak való kitettség során bekövetkező változásokat detektálja, megbecsülje a súlyosságát, ezzel lehetővé téve a megfelelő terápia megtervezését.

Enyhébb esetben, citokinek felhasználásával, pl IL-7, keratinocita növekedési faktor, FLT-3 G-CSF, GMCSF, SCF, és IL-3 és ezek kombinációjával lehet támogatni az új sejtek képződését. Az immunszupresszió miatt és mert a hámok barrierfunkciója is sérülhet, antibiotikum adása is indokolt lehet. 7-10 Gy közt csontvelő és őssejtátültetés megfelelő lehet. Alotranszplantációra jelentkező sérültek esetében a súlyos trauma vagy jelentős sérülés kizáró tényező. Ha ikertestvérrel vagy autológ tárolt csontvelövel vagy vér őssejtekkel rendelkezhetnek, akkor az átültetés küszöbértéke 4 Gy [5].

Az ionizáló sugárzás hatására bekövetkező egyszálú és kétszálú DNS-törések közvetlen molekuláris következményei nyomon követhetök fluoreszcens jelölésekkel, amelyek fehérjék változásait mutatják, mint például a $\mathrm{H} 2 \mathrm{AX}$ hisztonfehérje foszforilációja a DNS törések mentén. Ezen technikák egy része alkalmazható és automatizálható, igen jó szenzitivitással bír alacsony dózistartományban is, de nagy hátrányuk a dozimetria szempontjából, hogy a kimutatott jelenségek nem stabilak az időben. A hisztonfoszforiláció vizsgálatával viszont a sugárterápiára váró emberek esetén a sugárérzékenység meghatározásához, illetve sugárhatást módosító vegyületek kutatásához használható adatokat kaphatunk. 
A PCC-módszer, amely limfociták kínai hörcsög ovárium sejtekkel való fúziójával kondenzálja azok kromoszómáit, standard mikroszkópos eljárással ad dózisbecslést, lineáris kalibrációs görbe alapján. A módszert viszonylag kevés helyen alkalmazzák, mivel magasszintü képzettséget igényel és a besugárzástól számított rövid ideig (napok) ad pontos becslést.

A sugárzás által indukált kromoszóma-aberrációk (mint például a dicentrikus kromoszómák, vagy az acentrikus fragmentek), valamint a citogenetikai sérülések mikronukleusz formájában történő megjelenésének mennyiségi meghatározása rutinszerüen alkalmazott eljárás a dózisbecslésre. Ezen módszerek szenzitivitása és specificitása meglehetösen jó, részben automatizálhatóak és kivitelezhetők átlagosan felszerelt laboratóriumi körülmények között.

A FISH-módszerrel kimutatható transzlokációk meghatározása különösen a távoli múltban történt besugárzások esetén lehet hasznos, azonban az eredmények néha megkérdőjelezhetőek.

A sugárzás által indukált biokémiai indikátorokat már tesztelték a 80-as években, de csak kevés bizonyult specifikusnak a sugárzásra és még egyiket sem sikerült müködőképes módszerré fejleszteni. A jelenlegi nagy áteresztőképességü rendszerek (mRNS chipek stb.) ígéretessé teszik az integrált biológiai koncepciót, ahol több molekula (gének, fehérjék, metabolitok) fluktuációját van lehetőség egyszerre mérni és ez alapján felállítani egy kvalitatív, vagy kvantitatív karakterisztikus profilt az egyes dózisoknak való kitettség esetére. Jelenleg igen nagy potenciált jelentenek, különösen alacsony dózistartományban.

A biofizikai módszerek ígéretesek, mert alacsony dózistartományban is müködnek, specifikusak a sugárzásra és meglehetősen gyorsan szolgáltatnak eredmény. Szemben a vérrel, amely átkeveredik a szervezetben, ezek a szilárd minták (például: csont, fog) nem feltétlenül reprezentálják jól a test egészét ért dózist résztest besugárzás esetén.

Jelen közleménnyel azt céloztam meg, hogy a leggyakrabban és legáltalánosabban használt biodozimetriai eljárásokat áttekintsem, illetve röviden összehasonlítsam a fontosabb paramétereiket, valamint áttekintsem az ilyen célra potenciálisan alkalmazható korszerü eljárásokat. Ezt az összehasonlítást foglaltam össze az I. táblázatban, amely az egyes módszerek legfontosabb paramétereit veti össze.

A bemutatott módszerek - egymással kombinálva - alkalmasak lehetnek a feltételezhetően sugársérülést szenvedett személyek gyors és sokrétű vizsgálatára, legyen szó baleseti sérültek vagy misszióból hazatérő katonák kisebb-nagyobb csoportjáról. Mint láthatjuk az egyes módszerek legfontosabb paramétereikben (kimutathatóság küszöbértéke, az elvégzés ideje, a hatás időbeni kimutathatósága) jelentősen eltérhetnek egymástól. Minden körülmények között ideális módszer nincs, célszerü a használandó módszert a vizsgálandó események tükrében kiválasztani. A legtökéletesebb opció több módszer egyidejü használata, azonban ezt sok esetben (katasztrófa, terrortámadás) a mintaszámok és a rendelkezésre álló idő és a lehetőségek szűkössége nem teszi lehetővé.

Szempont még az automatizálhatóság, vagy legalább szemiautomatikus megoldás. Érdemesnek tartom megemlíteni azt is, hogy ugyanezek a módszerek alkalmasak sugárvédő anyagok és azok hatásmechanizmusának vizsgálatára is. 
I. táblázat. Az egyes biodozimetriai eljárások időablakai és kimutathatósági határértékei (Flood et al. 2014. [32] alapján, bövítve)

\begin{tabular}{|l|l|l|l|l|}
\hline Dicentrikus kromoszóma & $0-1$ nap & $>6$ hónap & $4-9$ nap & 0,1 Gy \\
\hline $\begin{array}{l}\text { Vérkép, limfocita szám } \\
\text { csökkenés }\end{array}$ & 12 óra & 48 óra & $1,5-2$ nap & $\sim 0,5$ Gy \\
\hline Mikronukleusz teszt & $0-1$ nap & 1 év & $4-6$ nap & $0,2-0,3$ Gy \\
\hline PCC & $0-1$ nap & 7 nap [4] & $\begin{array}{l}\text { CHO-23 óra kémiailag } \\
\text { indukált - 51 óra [4] }\end{array}$ & 0,2 Gy [4] \\
\hline FISH & $0-1$ nap & évek & 5 nap [7] & 0,5 (0,2) Gy \\
\hline Gamma H2AX & $3-30$ perc & $1-48$ óra & $1-2$ nap & 0,02 Gy \\
\hline Comet assay bázikus & kb. nincs & $30-45$ min [45] & kb. 1-2 nap & 0.05 Gy [45] \\
\hline $\begin{array}{l}\text { Comet assay semleges, dupla } \\
\text { száltörés }\end{array}$ & kb. nincs & $\begin{array}{l}0.5-4 \text { óra [44] } \\
72 \text { óra [53] } \\
1 \text { Gy fölött }\end{array}$ & kb. 1-2 nap & 0,125 Gy [53] \\
\hline Génexpresszió & 24 óra & $\begin{array}{l}\text { típusonként } \\
\text { változó }\end{array}$ & $2,5-17$ nap & 0,1 Gy [4] \\
\hline EPR & 0 & élethosszig & $<10$ perc & 0,05 Gy \\
\hline OSL & 0 & hónapok & 24 óra & 0,03 Gy \\
\hline
\end{tabular}

\section{Irodalom}

[1] Swartz, H.M., Flood, A.B., Gougelet R.M. et al.: A critical assessment of biodosimetry methods for large-scale incidents. Health Physics, 2010, 98(2): 95-108. DOI: 10.1097/ HP.0b013e3181b8cffd

[2] Flood, A.B., Ali, A.N., Boyle, H.K. et al.: Evaluating the Special Needs of the Military for Radiation Biodosimetry for Tactical Warfare against Deployed Troops: Comparing Military to Civilian Needs for Biodosimetry Methods. Health Physics, 2016, 111(2): 169-182. DOI: 10.1097/ HP.0000000000000538

[3] Somosy Z., Galántai R.T., Horváth GY. et al.: A szomszédsági hatás és lehetséges szerepe az arterioszklerotikus folyamatokban. Honvédorvos, 2012, 64(3-4): 185-201.

[4] Sullivan, J.M., Prasanna P.G.S., Grace, M.B. et al.: Assessment of Biodosimetry Methods for a Mass-Casualty Radiological Incident: Medical Response and Management Considerations. Health Physics, 2013, 105(6): 540-54. DOI: 10.1097/HP.0b013e31829cf221

[5] Dainiak, N., Waselenko, J.K., Armitage J.O. et al.: The Hematologist and Radiation Casualties, Hematology, Am. Soc. Hematol.
Educ. Program. 2003, 473-96. DOI: 10.1182/ asheducation-2003.1.473

[6] Kis E.: A NAÜ citogenetikai biodozimetria tanfolyama: Alkalmazás a nukleáris veszélyhelyzetre való felkészültségben és reagálásban. Sugárvédelem, 2013, 6(1): 38-43.

[7] Ainsbury, E.A., Bakhanova, E., Barquinero, J.F. et al.: Review of retrospective dosimetry techniques for external ionising radiation exposure. Radiation Protection Dosimetry, 2011, 147(4): 573-592. DOI: $10.1093 / \mathrm{rpd} /$ ncq499

[8] Pesznyák CS., Sáfrány G.: Sugárbiológia. Budapest: Typotex Kiadó, 2016.

[9] Voisin, P.: Standards in biological dosimetry: A requirement to perform an appropriate dose assessment. Mutation Research, 2015, 793: 115-122. DOI: 10.1016/j. mrgentox.2015.06.012

[10] Romm, H., Oestreicher, U., Kulka, U.: Cytogenetic damage analysed by the dicentric assay. Ann. Ist. Super. Sanita, 2009, 45(3): 251259.

[11] International Atomic Energy Agency: Cytogenetic analysis for radiation dose assessment. A manual. IAEA Technical Report Series, 2001, 405. 
[12] Turai I., Köteles Gy. (szerk.): Sugáregészségtan. Budapest: Medicina Kiadó, 2014.

[13] Fenech, M.: The cytokinesis-block micronucleus technique: a detailed description of the method and its application to genotoxicity studies in human populations. Mutation Research, 1993, 285(1): 35-44. DOI: 10.1016/0027-5107(93)90049-1

[14] Lucia Cytogenetics, http://www.lucia.cz/en/ front-page

[15] Repin, M., Pampou, S., Karan, C. et al.: RABiT-II: Implementation of a HighThroughput Micronucleus Biodosimetry Assay on Commercial Biotech. Robotic Systems. Radiat Research, 2017, 187(4): 492498. DOI: 10.1667/RR011CC. 1

[16] Rossnerova, A., Spatova, M., Schunck, C. et al.: Automated scoring of lymphocyte micronuclei by the MetaSystems Metafer image cytometry system and its application in studies of human mutagen sensitivity and biodosimetry of genotoxin exposure. Mutagenesis, 2011, 26(1): 169-175. DOI: 10.1093/mutage/geq057

[17] Terzoudi G.I., Pantelias G.E.: Cytogenetic methods for biodosimetry and risk individualization after exposure to ionising radiation. Radiation Protection Dosimetry, 2006, 122(14): 513-520. DOI: $10.1093 / \mathrm{rpd} / \mathrm{ncl} 509$

[18] International Atomic Energy Agency: Cytogenetic Dosimetry: Applications in Preparedness for and Response to Radiation Emergencies. IAEA, Vienna, 2011.

[19] Pantelias, G.E., Maillie H.D.: The use of peripheral blood mononuclear cell prematurely condensed chromosomes for biological dosimetry. Radiation Research, 1984, 99(1): 140-150.

[20] Lamadrid Boada, A.I., Romero Aguilera, I., Terzoudi, G.I. et al.: Rapid assessment of high-dose radiation exposures through scoring of cell-fusion-induced premature chromosome condensation and ring chromosomes. Mutat Research, 2013, 757(1): 45-51. DOI: 10.1016/j.mrgentox.2013.06.021

[21] Pantelias, G.E., Iliakis, G.E., Sambani, C.D. et al.: Biological dosimetry of absorbed radiation by C-banding of interphase chromosomes in peripheral blood lymphocytes. Int.
J. Radiat. Biol., 1993, 63(3): 349-354. DOI: 10.1080/09553009314550461

[22] M'kacher, R., El Maalouf E., Terzoudi, G. et al.: Detection and automated scoring of dicentric chromosomes in non-stimulated lymphocyte prematurely condensed chromosomes following telomere and centromere staining. Int. J. Rad. Oncology Biol. Physics, 2015, 91(3): 640-649. DOI: 10.1016/j. ijrobp.2014.10.048

[23] Karachristou, I., Karakosta, M., Pantelias, A. et al.: Triage biodosimetry using entromeric/ telomeric PNA probes and Giemsa staining to score dicentrics or excess fragments in non-stimulated lymphocyte prematurely condensed chromosomes. Mutat. Res. Genet. Toxicol. Environ. Mutagen, 2015, 793: 107114. DOI: 10.1016/j.mrgentox.2015.06.013

[24] Terzoudi, G.I., Pantelias, G., Darroudi, F. et al.: Dose assessment intercomparisons within the RENEB network using G0-lymphocyte prematurely condensed chromosomes (PCC assay). Int. J. Radiat Biol., 2017, 93(1): 48-57. DOI: $10.1080 / 09553002.2016 .1234725$

[25] Darroudi, F., Fomina, J., Meijers, M. et al.: Kinetics of the formation of chromosome aberrations in X-irradiated human lymphocytes, using PCC and FISH. Mutation Research, 1998, 404(1-2): 55-65. DOI: 10.1016/ S0027-5107(98)00095-5

[26] Tawn, E.J., Whitehouse, C.A.: Persistence of translocation frequencies in blood lymphocytes following radiotherapy: implications for retrospective radiation biodosimetry. J. Radiol. Prot., 2003, 23(4): 423-430. DOI: 10.1088/0952-4746/23/4/005

[27] Lloyd, D.C., Moquet, J.E., Oram, S. et al.: Accidental intake of tritiated water: a cytogenetic follow-up case on translocation stability and dose reconstruction. Int. J. Rad. Biol., 1998, 73(5): 543-547. DOI: 10.1080/095530098142095

[28] Lindholm, C., Edwards, A.: Long-term persistence of translocations in stable lymphocytes from victims of a radiological accident. Int. J. Rad. Biol., 2004, 80(8): 559566. DOI: $10.1080 / 09553000412331283498$

[29] Edwards, A.A., Lindholm, C., Darroudi, F., et al.: Review of translocations detected by 
FISH for retrospective biological dosimetry applications. Rad. Prot. Dosimetry, 2005, 113(4): 396-402. DOI: $10.1093 / \mathrm{rpd} /$ nch 452

[30] Whitehouse, C.A., Edwards, A.A., Tawn E.J. et al.: Translocation yields in peripheral blood lymphocytes from control populations. Int. J. Rad. Biol., 2005, 81(2): 139-145. DOI: $10.1080 / 09553000500103082$

[31] Sigurdson, A.J., Ha, M., Hauptmann, M. et al.: International study of factors affecting human chromosome translocations. Mutation Research, 2008, 652(2): 112-121. DOI: 10.1016/j.mrgentox.2008.01.005

[32] Flood, A.B., Boyle, H.K., Du, G. ET AL.: Advances in a framework to compare bio-dosimetry methods for triage in large-scale radiation events. Rad. Prot. Dosimetry, 2014, 159(1-4): 77-86. DOI: $10.1093 / \mathrm{rpd} / \mathrm{ncu} 120$

[33] Rogakou, E.P., Boon, C., Redon, C. et al.: Megabase chromatin domains involved in DNA double-strand breaks in vivo. J. Cell Biology, 1999, 146(5): 905-915. DOI: 10.1083/jcb.146.5.905

[34] Schmidt-Ullrich, R.K., Dent, P., Grant, S. et al.: Signal transduction and cellular radiation responses. Rad. Research, 2000, 153(3): 245-257. DOI: 10.1667/0033-7587 (2000) 153[0245:STACRR]2.0.CO;2

[35] Pilch, D.R., Sedelnikova, O.A., Redon, C. et al.: Characteristics of gamma-H2AX foci at DNA double-strand breaks sites. Biochem. Cell Biol., 2003, 81(3): 123-129. DOI: 10.1139/o03-042

[36] Redon, C., Pilch, D., Rogakou, E., et al.: Histone $\mathrm{H} 2 \mathrm{~A}$ variants $\mathrm{H} 2 \mathrm{AX}$ and H2AZ. Curr. Opin. Genet. Dev., 2002, 12(2): 162169. DOI: $10.1016 / S 0959-437 \mathrm{X}(02) 00282-4$

[37] Sedelnikova, O.A., Pilch, D.R., Redon, C. et al.: Histone H2AX in DNA damage and repair. Cancer Biol. Ther., 2003, 2(3): 233235. DOI: $10.4161 /$ cbt.2.3.373

[38] Sedelnikova, O.A., Horikawa, I., Redon, C. et al.: Delayed kinetics of DNA double-strand break processing in normal and pathological aging. Aging Cell, 2008, 7(1): 89-100. DOI: 10.1111/j.1474-9726.2007.00354.x

[39] Redon, C.E., Dickey, J.S., Bonner, W.M. et al.: $\gamma-\mathrm{H} 2 \mathrm{AX}$ as a biomarker of DNA damage induced by ionizing radiation in human peripheral blood lymphocytes and artificial skin. Adv Space Res., 2009, 43(8): 1171-1178. DOI: $10.1016 /$ j.asr.2008.10.011

[40] Garty, G., Chen, Y., Salerno, A. et al.: The RABIT: a rapid automated biodosimetry tool for radiological triage. Health Physics, 2010, 98(2): 209-217. DOI: 10.1097/HP.0b013e$3181 \mathrm{ab} 3 \mathrm{cb} 6$

[41] Kis E., Solymosi J., Sáfrány G.: A sugárérzékenység vizsgálatának katasztrófavédelmi jelentősége. Hadmérnök, 2013, 8(4): 104-112.

[42] Gunasekarana, V., Raj, G.J., Chand, P.: A Comprehensive Review on Clinical Applications of Comet Assay. J. Clin. Diag. Res., 2005, 9(3): GE01-GE05. DOI: 10.7860/ JCDR/2015/12062.5622

[43] Li, J., Wang, Y., Du, L. et al.: Nested PCR for mtDNA 4977 bp deletion and comet assay for DNA damage a combined method for radiosensitivity evaluation of tumor cells. Oncology Letters, 2014, 7(4): 1083-1087. DOI: $10.3892 /$ ol.2014.1819

[44] Zhao, J., Guo, Z., Zhang, H., et al.: The potential value of the neutral comet assay and $\gamma \mathrm{H} 2 \mathrm{AX}$ foci assay in assessing the radiosensitivity of carbon beam in human tumor cell lines. Radiol. Oncol., 2013, 43(3): 247-257. DOI: 10.2478/raon-2013-0045

[45] Vijayalaxmi, Tice, R.R., Strauss, G.H.: Assessment of radiation-induced DNA damage in human blood lymphocytes using the single-cell gel electrophoresis technique. Mutation Research, 1992, 271(3): 243-52. DOI: 10.1016/0165-1161(92)90019-i

[46] Deperas-Kaminska, M., Bajinskis A., Marczyk M. et al.: Radiation-induced changes in levels of selected proteins in peripheral blood serum of breast cancer patients as a potential triage biodosimeter for large-scale radiological emergencies. Health Physics, 2014, 107(6): 555-563. DOI: 10.1097/ HP.0000000000000158

[47] Paul, S., Amundson, S.A.: Development of gene expression signatures for practical radiation biodosimetry. Int. J. Radiat. Oncol. Biol. Phys., 2008, 71(4): 1236-1244. DOI: 10.1016/j.ijrobp.2008.03.043 
[48] Lee, Y., Canadell, MP., Shuryak, I., et al.: Candidate protein markers for radiation biodosimetry in the hematopoietically humanized mouse model. Scientific Reports, 2018, 813557, DOI: 10.1038s41598-018-31740-8

[49] Anderson, S., Bankier, AT., Barrell, B.G. et al.: Sequence and organization of the human mitochondrial genome. Nature, 1981, 290: 457-465.

[50] Clayton, D.A.: Replication and transcription of vertebrate mitochondrial DNA. Ann. Rev. Cell Bioi., 1991, 7: 453-78. DOI: 10.1146/ annurev.cb.07.110191.002321

[51] Damas, J., Carneiro, J., Amorim, A. et al.: MitoBreak: the mitochondrial DNA breakpoints database. Nucleic Acids Res., 2014, 42 (Database issue): D1261-8. DOI: 10.1093/nar/gkt982.

[52] Swartz, H.M., Williams, B.B., Flood, A.B.: Overview of the principles and practice of biodosimetry. Rad. Env. Biophys., 2014, 53(2): 221-232. DOI:10.1007/s00411-0140522-0.

[53] Wang, Y., Xu, C., Du, L.Q. et al.: Evaluation of the Comet Assay for Assessing the DoseResponse Relationship of DNA Damage Induced by Ionizing Radiation. Int. J. Mol. Sci., 2013, 14(11): 22449-22461. DOI: 10.3390/ijms 141122449

\section{G. Deli}

\section{Detectional tools for effects of ionizing radiation on the human body}

Ionizing radiation hits our body more often than we expect. We are permanently exposed to background radiation from the Earth's crust and from cosmic space. In the event of a catastrophe, radiation incident or terrorist attack people may receive a higher dose of ionizing radiation. These exposures, in addition to acute symptoms, can cause long-term health problems, and can develop tumors in the years following irradiation.
In cases where the person did not wear a dosimeter, the incoming dose can be estimated by various biodosimetric measurements. A common feature of these methods is the detection of changes in the individual's cells after exposure to ionizing radiation, thereby enabling the design of appropriate therapy. Irradiation results in chromosome aberrations, one of which, the dicentric form, is specific for ionizing radiation. The main disadvantages of this classical cytogenetic method are that it needs time-consuming cell culturing and the microscopic evaluation is subjective. In cases where a large number of people are affected, some faster methods are needed to prescreen and to reduce the number of people to be examined. Many biodosimetric methods are already available or under development. For example, micronucleus assay is also a cytogenetic method, but its evaluation is faster. Protein markers can also be useful tools, such as the $\gamma$-H2AX histone protein, which marks double strand breaks in DNA. Comet assay is a single-cell electrophoresis, DNA forms a "comet" in the gel, and the more fragmented the DNA, the longer the comet's tail. Mitochondrial DNA is more sensitive to radiation than nuclear. Deletions resulting from an error in the repair process can be detected by PCR. Radiation-expressed proteins and their mRNAs can also be detected. This summary provides a brief overview of biodosimetric methods.

Keywords: biodosimetry, micronucleus, chromosome aberrations, $\gamma$-H2AX, comet assay, mitochondrial DNA, $m R N A$ and protein markers.

Deli Gábor 1134 Budapest, Róbert Károly krt. 44. 